\title{
Contractual Successorship: The Impact of Burns
}

One of the primary goals of the Labor Management Relations Act (LMRA) ${ }^{1}$ is to encourage unions and management to enter voluntarily into collective bargaining agreements governing the terms and conditions of work. Toward this end, the LMRA requires the parties in a collective bargaining relationship to bargain in good faith. ${ }^{2}$ The duty to bargain in good faith does not, however, imply a duty to agree. Consistent with its fundamental premise that mutually acceptable terms provide the only sound basis for a collective bargaining agreement, the LMRA provides that neither union nor employer can be forced to accept a contract, or any term of a contract to which they do not voluntarily agree. ${ }^{3}$

An apparent exception to this principle was created by the Supreme Court in John Wiley or Sons v. Livingston, ${ }^{4}$ which held that an employer who acquired a business by merger could be compelled to honor the arbitration provisions of a collective bargaining contract that had been negotiated by his predecessor but that he had not agreed to assume. The Court acknowledged that under traditional rules of contract the successor employer might not be bound by the agreement unless he expressly consented to assume it; nonetheless, it concluded that the interest of the public and the employees would be better served by arbitration, because arbitration would reduce the potential for strikes and other forms of economic disruption likely to flow from an unanticipated termination of the collective bargaining agreement. ${ }^{5}$ Although Wiley held only that the successor employer was required to honor the arbitration provisions of the contract, the Court expressly indicated that the arbitrator could find that other terms of the collective bargaining agreement survived the merger. ${ }^{6}$ An employer who had consistently refused to agree to any of the provisions of the old collective bargaining

129 U.S.C. $\$ \$ 151-68$ (1970).

2 LMRA § 8(d), 29 U.S.C. 158(d) (1970).

$3 I d$. Section 8(d) of the Act is discussed in text and notes at notes 30-33 infra.

4376 U.S. 543 (1964).

6 For a discussion of some of the tensions produced by the sale of a business covered by a collective bargaining agreement, see generally Doppelt, Successor Companies: The NLRB Limits The Options-And Raises Some Problems, 20 DE PAUL L. REV. 176 (1971).

c 376 U.S. at 555 . 
agreement might thereby be compelled by the arbitrator to accept all of them.

The Supreme Court limited Wiley's exception in NLRB v. William J. Burns International Security Services, Inc., ${ }^{7}$ holding that the National Labor Relations Board (NLRB) could not order a successor employer to assume the collective bargaining agreement entered into by the previous employer. The decision was predicated on section 8(d) of the LMRA, ${ }^{8}$ which expressly prohibits compelling a reluctant party to make a concession or agree to a contract proposal. The Court said: "Congress has consistently declined to interfere with free collective bargaining and has preferred that device, or voluntary arbitration, to the imposition of compulsory terms as a means of avoiding or terminating labor disputes."

Burns and Wiley are not easily reconciled. Burns emphasized the voluntary nature of collective bargaining agreements, while Wiley found that the strong preference of national labor relations policy for arbitration as a means of dispute settlement overcame the fact that the successor had not signed a collective bargaining agreement with an arbitration provision. This tension between Wiley and Burns creates significant doubt about the continued vitality of Wiley's contractual successorship rule. It is difficult to justify a court's decision to impose the arbitration clause of a collective bargaining agreement on a nonconsenting successor employer after Burns's holding that the LMRA's freedom of contract principles bar the Board from ordering a successor employer to honor any provisions of a collective bargaining agreement that he has not explicitly agreed to assume. It may be, however, that Burns should be read not so much as a general affirmation of the voluntary nature of collective bargaining agreements in successorship cases, but as a statement of the limitations governing the Board's ability to provide contractual remedies in successorship cases. On this view of Burns, the Wiley rule that the successor can be compelled without prior agreement to arbitrate the survival of the contract may still be applied by the courts.

This comment first discusses the doctrine of contractual successorship articulated in Wiley and Burns. The analysis concludes that although Burns's "freedom of contract" rationale could readily apply to deny the courts, as well as the Board, the power to order nonconsenting successors to arbitrate successorship issues, this result is not required because the federal courts have a special institutional role in fashioning

7406 U.S. 272 (1972).

829 U.S.C. I58(d) (1970).

9406 U.S. at 282. 
rules for the enforcement of collective bargaining contracts, which may partially exempt them from the LMRA's prohibitions against imposing contract obligations on nonconsenting parties. It is argued that such an exemption can be justified only if the successorship concept is necessary to promote the stability of collective bargaining agreements. The successorship doctrine is then examined in terms of its impact on employers and unions, and it is suggested that its consequences are not consistent with the aims of national labor relations policy and that the doctrine is not necessary for the protection of collective bargaining relationships. Finally, the comment analyzes the role of the arbitrator in successorship cases, and concludes that the courts should not rely on the arbitrator to determine the extent to which a collective bargaining agreement binds a successor employer, because such reliance would deprive the employer of his constitutional right to have legal disputes adjudicated by a court of law.

\section{Wiley, Burns, AND THE SUCcesSORSHIP DOCTRINE10}

The successorship doctrine was first applied to collective bargaining agreements by the Supreme Court in John Wiley \& Sons v. Livingston.11 In Wiley, a small corporation, whose employees were covered by a union contract, merged into a larger nonunionized corporation in the same line of business. The union had unsuccessfully demanded prior to the merger that the acquiring corporation agree to assume the collective bargaining agreement. Business operations at the acquired corporation were unaffected by the merger, but the collective bargaining agreement

10 This comment deals exclusively with the successorship rule as applied to collective bargaining contracts. The successorship concept is also applicable to other areas of labor law. The doctrine was initially developed by the Board to require successor employers to remedy unfair labor practices committed by a previous employer. See Tom-A-Hawk Transit, Inc. v. NLRB, 419 F.2d 1025 (7th Cir. 1969); NLRB v. Colten, 105 F.2d 179 (6th Cir. 1939); Perma Vinyl Corp., 164 N.L.R.B. 968, 65 L.R.R.M. 1168, enforced sub nom., United States Pipe \& Foundry Co. v. NLRB, 398 F.2d 544 (5th Cir. 1968). The doctrine also encompasses union representation, so that an employer may now be required to recognize and bargain with a union which has gained majority status under a previous employer, provided there has not been significant change in the bargaining unit, and a majority of the employees hired by the successor employer are members of the union. NLRB v. William J. Burns Int'l Security Services, Inc., 406 U.S. 272 (1972); NLRB v. Zayre Corp., 424 F.2d 1159 (5th Cir. 1970). Although contractual successorship has much in common with these other applications of the successorship concept, they do not necessarily overlap, as illustrated by the Supreme Court's decision in Burns, holding that the successor employer had a duty to recognize and bargain with the union, but was not required to honor the collective bargaining agreement. For a general discussion of the variety of applications of the successorship concept in labor law, see Swerdlow, Freedom of Contract in Labor Law: Burns, H.K. Porter, and Section 8(d), 51 TexAs L. REv. (1972).

11376 U.S. 543 (1963), aff'g 313 F.2d 52 (2d Cir.), rev'g 203 F. Supp. 171 (S.D.N.Y. 1962). 
was no longer complied with. ${ }^{12}$ The union brought suit under section 301 of the LMRA, ${ }^{13}$ arguing that the acquiring corporation was required to arbitrate the issue of whether it was bound by the collective bargaining agreement.

The Supreme Court held that the acquiring corporation must arbitrate the dispute, because the arbitration clause "survived" the merger. Recognizing that the nonconsenting successor would not ordinarily be bound to a contract of his predecessor, the Court found that the successor employer's lack of consent was overcome by "the preference of national labor policy for arbitration as a substitute for tests of strength" 14 by economic warfare between labor and management. The Court emphasized that the collective bargaining agreement was more than an ordinary contract, and resembled instead a compact or constitution establishing the basic legal framework of the employment relationship. ${ }^{15}$ In stressing this aspect of collective bargaining agreements, the Court seemed to suggest that such contracts have an existence independent of the original parties to the agreement. The Court went on to indicate that in appropriate circumstances the arbitrator is permitted to rule that the successor employer is bound to the substantive provisions of the collective bargaining agreement. Arbitrators in successorship cases have followed this suggestion, ruling that successor employers are liable in appropriate circumstances under the collective bargaining contracts of their predecessors. ${ }^{16}$

Wiley did not require all successor employers to arbitrate the survival of collective bargaining contracts. The Court said that, unless there is substantial "continuity of identity in the business" before and after the change of ownership, the successor employer might not be bound by the arbitration clause. ${ }^{17}$ The Gourt found substantial business continuity in Wiley, because virtually all the union employees remained on

12 The new management notified the union members that henceforth the collective bargaining contract with the previous employer would not be honored, although the union employees would receive credit for their seniority and pension plan contributions under the system of employee benefits offered by the new management.

1329 U.S.C. \& 185 (1970). Section 301 provides for federal court jurisdiction to enforce collective bargaining contracts, including jurisdiction to order specific performance of arbitration clauses. See Textile Workers Union v. Lincoln Mills, 353 U.S. 448 (1957), and text and notes at notes $42-46$ infra.

14376 U.S. at 549.

15 Id. at 550. For an extensive discussion of the special qualities of collective bargaining contracts, see generally Shulman, Reason, Contract and Law in Labor Relations, 68 HARV. L. REv. 999 (1955).

16 See, e.g., Interscience Encyclopedia, Inc., 55 Lab. Arb. 210 (1970) (Roberts, Arbitrator) (the Wiley arbitration); Sanborn's Motor Express, Lab. Arb. 346 (1965) (Wallen, Arbitrator).

17376 U.S. at 551. 
the job for a time after the merger, and the operations of the acquired enterprise were not altered by the merger. ${ }^{18}$ Lower court interpretations of Wiley have established a two-part test for determining whether there is sufficient business continuity to order a successor employer to arbitrate. ${ }^{19}$ First, there must be sufficient continuity in the work force; a substantial percentage of the new employer's work force must be made up of the union employees of the previous employer. ${ }^{20}$ The second element is the requirement of enterprise continuity. The successor employer must continue to operate essentially the same "business" in the same manner as his predecessor. ${ }^{21}$ This part of the successorship test was held satisfied where the successor employer acquired the business by means other than a merger. ${ }^{22}$ When both elements of business continuity are present, the courts will order the successor employer to arbitrate the union's claim that the collective bargaining agreement remains in force. ${ }^{23}$

A number of justifications have been advanced for requiring a successor employer to arbitrate the question of his obligations under the collective bargaining agreement. ${ }^{24}$ First, the expectations of employees

18 The acquiring corporation operated the acquired business in the same facilities, using the same personnel, for about four months, at which time operations were terminated, and some of the union employees were transferred to the facilities of the acquiring corporation and intermingled with the nonunion employees of the acquiring corporation. Interscience Encyclopedia, Inc., 55 Lab. Arb. 210 (1970).

19 See, e.g., United States Gypsum Co. v. United Steelworkers of America, 384 F.2d 38 (5th Gir. 1967), cert. denied, 389 U.S. 1042 (1968); United Steelworkers of America v. Reliance Universal, Inc., 335 F.2d 891 (3d Gir. 1964); Wackenhut Corp. v. United Plant Guard Workers of America, 332 F.2d 954 (9th Gir. 1964).

20 It is not clear whether the successorship obligation can be imposed where less than a majority of the successor's employees were union employees of the predecessor employer. See NLRB v. William J. Burns Int'1 Security Services, Inc., 406 U.S. 272, 281 n.6 (1972). See also Interstate 65 Corp., 186 N.L.R.B. 248, 75 L.R.R.M. 1403 (1970), enforced in part, 453 F.2d 269 (6th Cir. 1971).

21 This element of the successorship test appears to have relatively little relationship to the concerns prompting Wiley's successorship rule. However, it does seem to represent a necessary common sense limitation on the successorship rule. Unless the successor pursues virtually the same business as his predecessor, the existing contract provisions will not be relevant to conditions in the plant. See Local 75, Drivers Union v. State Employment Relations Board, 29 Wis. 2d 272, 138 N.W.2d 180 (1965). NLRB v. William J. Burns Int'l Security Services, Inc., 406 U.S. 272 (1972), may have changed this element of the successorship test by adding a requirement of some type of "privity" between the successor and predecessor employers.

22 Wackenhut Corp. v. Plant Guard Workers Union of America, 332 F.2d 954 (9th Cir. 1964).

23 The term "successor employer" is used in this comment to indicate only the fact that the employer has hired a number of union members previously employed in a related business, and not that the employer has any definite legal obligation as a result of employing these individuals.

24 See Bernstein, Labor Problems on Acquisitions and Sale of Assets, 22 N.Y.U. CoNF. on 
are secured against an unanticipated change that could deprive them of the benefits of their bargain. This argument favors employee expectations over the successor employer's freedom to negotiate a new contract. A second justification is that the public may benefit from a reduction in the likelihood of strikes or other forms of industrial disruption frequently associated with rapid and unforeseen changes in working conditions. A final argument rests on considerations similar to those that support preemption of state laws where federal law regulates the same field. Many states have laws that require the purchaser of a business, or the acquiring corporation in a merger, to assume the debts and other business obligations of the acquired business. ${ }^{25}$ In some circumstances these state laws may treat a collective bargaining agreement like other business obligations. ${ }^{26}$ But the state successorship laws are quite diverse, and usually were not written to accomodate the specialized concerns of national labor law. The substitution of a federal rule of contractual successorship would produce uniform results more in accord with national labor policy. The Court in Wiley appeared to rely to some extent on all three of these rationales.

Wiley's holding that the successor employer could be bound to the arbitration clause of the collective bargaining agreement proved to be an expansive one. In William J. Burns International Detective Agency, Inc., ${ }^{27}$ the NLRB extended Wiley and directly ordered Burns to honor all provisions of a collective bargaining contract negotiated by a previous employer. The previous employer, Wackenhut Corporation, was an independent contractor engaged to provide security services to a large industrial plant. Shortly before the expiration of Wackenhut's plant protection agreement, the NLRB certified the United Plant Guard Workers as the union for Wackenhut's employees, and the union and Wackenhut negotiated a collective bargaining agreement. Burns underbid Wackenhut in the competitive bidding for the next year's security services contract. Burns already had a collective bargaining agreement with a union representing all of Burns's guards in the geographic area,

LABOR 81 (1970); Doppelt, supra note 5; Goldberg, The Labor Law Obligations of a Successor Employer, 63 Nw. U.L. REv. 735 (1969); Note, The Successor Employer's Duty to Arbitrate: $A$ Reconsideration of John Wiley \& Sons, Inc. v. Livingston, 82 HaRv. L. REv. 418 (1968); Note, Contract Rights and the Successor Employer: The Impact of Burns Security, 71 Mich. L. REv. 571 (1973).

25 See, e.g., N.Y. Bus. CoRP. LAW § 906 (McKinney 1970); ABA-ALI MODEL Bus. Corp. ACT $\S 69$ (1953).

26 The argument for giving continued effect to the collective bargaining agreement is most compelling where the employer has merely made a technical change in the corporate structure, leaving the beneficial ownership of the business unaffected. Cf. Southport Petroleum Co. v. NLRB, 315 U.S. 100 (1942).

27182 N.L.R.B. 348, 74 L.R.R.M. 1098 (1970). 
and extended an offer of employment, on those terms, to the plant guards who had worked for Wackenhut.28 Twenty-seven accepted employment with Burns; fifteen other Burns guards were transferred in from other locations. The security services provided by Burns were substantially identical to those provided by the same personnel under Wackenhut's auspices. The union representing Wackenhut's former employees demanded to be recognized as the exclusive bargaining agent for all guards at the plant, and further demanded that Burns adhere to the terms and conditions of the agreement negotiated with Wackenhut. Burns refused both demands and the union filed a complaint with the NLRB. The Board found that Burns was a successor employer, and ordered it to recognize the union and to honor the collective bargaining agreement. ${ }^{29}$

Although it required Burns to recognize and bargain with the union, ${ }^{30}$ the Supreme Court held that Burns was not obligated to honor the collective bargaining agreement. The Court relied heavily on section $8(d)$ of the LMRA, which defines the collective duties of the parties and provides that the duty to bargain in good faith "does not compel either party to agree to a proposal or require the making of a concession." 31 The Court said that "[ $\mathrm{b}]$ argaining freedom means both that the parties need not make any concessions as a result of government compulsion and that they are free from having contractual provisions imposed on them against their will."32 This emphasis on freedom of

28 Burns not only refused to recognize the union, but it actively solicited its new employees to join the rival union with which Burns regularly dealt. The Board determined that Burns's assistance to the rival union violated LMRA $\S 8$ 8(a)(1)-(2), 29 U.S.C. $\$ \S$ 158(a)(1)-(2) (1970). William J. Burns Int'l Detective Agency, Inc., 182 N.L.R.B. 348, 74 L.R.R.M. 1098 (1970). Burns did not appeal this portion of the Board judgment.

29 The Burns case was the Board's first attempt to use the successorship doctrine to impose contractual obligations on a successor employer. There was, however, some language in the case law indicating that it would be proper to directly order the employer to assume that collective bargaining agreement, instead of arbitrating the survival of the contract. See Wackenhut Corp. v. United Plant Guard Workers, 392 F.2d 954 (9th Cir. 1964).

30 The Court held that in view of the NLRB's recent certification of the union, Burns could not have a good faith doubt as to the majority status of the union after hiring twenty-seven of its forty-two employees from the ranks of the union. Cf. NLRB v. Gissel Packing Co., 395 U.S. 575 (1969). The Chief Justice, and Justices Brennan, Powell, and Rehnquist dissented from this part of the Court's holding.

3129 U.S.C. 158(d). Section 8(d) provides in part:

For the purposes of this section, to bargain collectively is the performance of the mutual obligation of the employer and the representative of the employees to meet at reasonable times and confer in good faith with respect to wages, hours, and other terms and conditions of employment, or the negotiation of an agreement, or any question arising thereunder, and the execution of a written contract incorporation any agreement reached if requested by either party, but such obligation does not compel either party to agree to a proposal or require the making of a concession. . . . 32406 U.S. 272, 287 (1972). 
contract in collective bargaining is directly opposed to Wiley's view that collective bargaining agreements are "not in any real sense the simple product of a consensual relationship."33 Moreover, it is difficult to see how Wiley's rule that a nonconsenting successor may be bound to the arbitration clause of a collective bargaining agreement, and held liable for the other provisions of the contract by the arbitrator, is consistent with the holding in Burns. There are, however, some distinctions between the two cases. Wiley involved a merger in a state whose law required the surviving corporation to assume the business obligations of the disappearing corporation, ${ }^{34}$ while Burns did not acquire the business of the previous employer and was in fact a competitor of the previous employer. But it is doubtful that this lack of "privity" between the two employers should make any difference in view of Wiley's policy concerns. The employee's expectation interest and the public's interest in the peaceful settlement of labor disputes can be significantly affected even without privity between the predecessor and successor employers. This was recognized by the Board and the Second Circuit in Burns. ${ }^{35}$ A second distinction relied upon in Burns was that Wiley arose as a suit in federal court under section 301 of the LMRA, ${ }^{36}$ while Burns was an unfair labor practice case before the Board. At first glance this difference appears insignificant, since there is nothing in the LMRA or the legislative history of section 8 (d) that can be taken as condoning judicial imposition of contract obligations in circumstances in which the Board is barred from interfering with the freedom of contract. This distinction seems to imply that the union in Burns simply chose the wrong forum and that it should have sued in federal court on the arbitration clause of the collective bargaining agreement. ${ }^{37}$ Furthermore, the Court gave no indication why the federal courts should have greater latitude than the Board to require successor employers to honor collective bargaining agreements. Some possible justifications for this distinction are analyzed in the following section.

33376 U.S. 543 at 550 (1964).

34 L. 1923, ch. 737, October 1, 1923, Laws of N.Y. (repealed effective 1963).

35 William J. Burns Int'1 Detective Agency v. NLRB, 441 F.2d 911 (2d Cir. 1971), aff'd, 406 U.S. 272 (1972).

36 See text and notes at notes $40-43$ infra for a discussion of section 301's significance for successorship cases.

37 The collective bargaining agreement in Burns contained an arbitration clause. Appendix to Briefs at 152-54, NLRB v. William J. Burns Int'l Security Services, Inc., 406 U.S. 272 (1972). The union may have chosen to file its complaint with the Board, rather than seek arbitration, because of the unfair labor practice complaint involved in the case, or because it was less expensive to file a charge with the Board than to litigate a case in federal court. 


\section{Successorship After Burns}

The Burns decision creates a substantial doubt as to whether the federal courts, assisted by the arbitrator, may still compel successor employers to honor collective bargaining agreements to which they were never parties. The Court condemned not only Board-ordered contractual successorship, but also any variety of "official compulsion over the actual terms of the contract." 38 In fact, it was concern with the danger of governmentally imposed collective bargaining agreements that motivated Congress to enact section 8(d)'s explicit prohibition against forcing collective bargaining terms on unwilling parties. ${ }^{30}$ Resolution of this tension between Wiley on the one hand and Burns and section 8 (d) on the other may depend to a great extent on how the role of the federal courts in successorship cases is perceived.

\section{A. The Successorship Doctrine and the Federal Courts}

Section 301 of the LMRA gives the federal courts jurisdiction over suits to enforce collective bargaining agreements, ${ }^{40}$ including jurisdiction over successorship cases. The legislative history of section 301 indicates that Congress wanted to eliminate the difficulties that parties had previously experienced in enforcing collective bargaining agreements. ${ }^{41}$ Unless legal machinery adequate to enforce contract rights was readily available, the LMRA's efforts to encourage the use of

38 NLRB v. William J. Burns Int'l Security Services, Inc., 406 U.S. 272, 287 (1972), quoting H. K. Porter Co. v. NLRB, 397 U.S. 99, 108 (1970).

30 Congress expressed concern that, "the present Board has gone very far, in the guise of determining whether or not employers had bargained in good faith, in setting itself up as the judge of what concessions an employer must make and the proposals and counterproposals that he may or may not make .... [U]nless Congress writes into the law guides for the Board to follow, the Board may attempt to carry this process still further and seek to control more and more of the terms of collective bargaining agreements." H.R. REP. No. 245, 80th Cong., 1st Sess., 19-20 (1947), reprinted in 1 LeGisLATIVE History of the Labor Management Relations Acr, 1947, at 310-11 (1948). For an extensive discussion of the legislative history of section $8($ d), see H.K. Porter Co., Inc. v. NLRB, 397 U.S. 99 (1970).

40 LMRA § 301(a), 29 U.S.C. \& 185(a) (1970), provides:

Suits for violation of contracts between an employer and a labor organization representing employees in an industry affecting commerce as defined in this Act, or between any such labor organizations, may be brought in any district court of the United States having jurisdiction of the parties, without respect to the amount in controversy or without regard to the citizenship of the parties.

41 S. REp. No. 105, 80th Cong., Ist Sess. 17, reprinted in 1 Legislative History of THE LABOR MANAGEMENT RELATIONS ACT, 1947, at 423 (1948), summarized the purpose of section 301 as follows: "Statutory recognition of the collective bargaining agreement as a valid, binding, and enforceable contract is a logical and necessary step. It will promote a higher degree of responsibility upon the parties to such agreements, and will thereby promote industrial peace. 
collective bargaining agreements as the primary means of regulating labor relations would be frustrated. Textile Workers Unions $v$. Lincoln $M_{i l l s^{42}}$ established, however, that section 301 was more than a bare grant of jurisdiction; it reflected the congressional desire to provide an efficient and dependable means for enforcing collective bargaining contracts, and, therefore, empowered the federal courts to create a federal common law of collective bargaining agreements. The Court concluded in Lincoln Mills that while federal law must be the exclusive source of rights enforced under section 301, "state law, if compatible with the purpose of section 301 , may be resorted to in order to find the rule that best effectuates the federal policy." 43

The Supreme Court's decision in Wiley can be seen as a further articulation of the new federal common law that the courts have developed since Lincoln Mills.44 The union in Wiley had urged the Court to rely on New York's merger law, which required the acquiring corporation in a merger to assume the business obligations of the acquired corporation. ${ }^{45}$ But in order to fashion a remedy in Wiley, it was necessary to expand the federal common law because, under Lincoln Mills, section 301 empowered courts to enforce (and create) federal common law, not state created rights. ${ }^{46}$ The successorship rule was, therefore, added to the federal common law of collective bargaining agreements.

Lincoln Mills's discussion of what substantive law to apply in section 301 suits emphasized that the federal courts should look to state law as a guide to the federal rights provided by section 301 . It is reasonable that the federal common law of collective bargaining agreements follow state laws, such as New York's merger statute, in the provision of the usual kinds of contract rights and remedies. Unless collective bargaining contract rights are given protection through a body of remedial law that increases the certainty that these rights will be enforcible, parties will not be encouraged to enter collective bargaining contracts. Failure to provide such remedies would frustrate the purpose of section 301 .

Given the legislative purpose behind section 301, as construed in Lincoln Mills, it may be possible to reconcile Burns's and Wiley's

42353 U.S. 448 (1957).

$43 \mathrm{Id}$. at 457.

44 See Ratner, Emergent Role of the District Courts in National Labor Policy, 17 LAB. L. J. 36 (1966).

45 L. 1923, ch. 737, October 1, 1923, Laws of N.Y. (repealed effective 1963).

$46 \mathrm{Had}$ section 301 been construed as conferring jurisdiction to enforce state created rights-rights not somehow imported into federal law-it would have conflicted with Article III of the Constitution granting the federal courts jurisdiction over state-created causes of action. See Textile Workers Union v. Lincoln Mills, 353 U.S. 448, 460 (1957) (Frankfurter, J., dissenting). 
divergent views on the propriety of imposing contractual obligations on a successor employer. Burns's refusal to allow the Board to enforce the collective bargaining contract against the successor is understandable, because only the federal courts and not the Board have authority under section 301 to apply the federal common law of collective bargaining agreements. Furthermore, Wiley may be good law despite Burns's emphasis on freedom of contract in collective bargaining, and section 8(d)'s express proviso against imposing contractual obligations on nonconsenting parties. Wiley can be justified in terms of the purpose behind section 301 , because the successorship rule can be viewed as one means of increasing the stability and certainty of the contractual rights that each party has bargained for. Under this interpretation of Wiley and Burns the successor employer's freedom of contract must give way, in appropriate circumstances, to the need to protect the legitimate expectation of the original parties to the collective bargaining agreement that their contract rights will prove durable.

The propriety of balancing the policies underlying section 301 and section 8(d) to accommodate both Wiley and Burns depends primarily on whether the successorship rule is a necessary and effective means of protecting the expectations of parties to a collective bargaining agreement, creating a greater willingness to strike bargains. Unless it is clear that Wiley's successorship rule enhances the stability of collective bargaining agreements, there is little justification for overriding freedom of contract principles basic to the LMRA. The next section suggests that the successorship rule may not be as necessary for protecting the stability of collective bargaining relationships as Wiley assumed.

\section{B. The Costs of Successorship}

The majority of commentators agree that the successorship rule is on the whole desirable. ${ }^{47}$ Little effort has been devoted, however, to assessing the character of the benefits derived from the rule, or to comparing these benefits with the rule's costs. The Wiley Court predicated its decision upon two major benefits of the rule: first, union members would have better protection of their expectations derived from the existing collective bargaining agreement, and second, the public would benefit because a potential source of strikes and economic conflict would be eliminated..$^{48}$ Neither of these benefits is costless, nor is it certain that the successorship rule will produce them.

47 See, e.g., Doppelt, supra note 5; Goldberg, supra note 24; Note, The Successor-Employer's Duty to Arbitrate, supra note 24; Note, Contract Rights and the Successor Employer: The Impact of Burns Security, supra note 24. But see Swerdlow, supra note 10.

48 See text and notes at notes 24-26 supra. 
There are a number of administrative costs associated with the successorship rule. One of the most significant of these costs is created by the uncertainties attending the application of the rule. Wiley's business continuity test involves a number of questions of degree that cannot easily be answered. ${ }^{49}$ It is still not clear how much change there can be in the operations of the business, or turnover in the personnel, before the new employer will be held not to be a successor employer. ${ }^{50}$ If successorship is found, further uncertainties are introduced by arbitration of successorship disputes. The arbitrator is not required to follow precedent, and his awards are not subject to extensive review. ${ }^{\text {b1 }}$ Furthermore, because the successorship obligation may be avoided if the employer hires only a few former members of the union, ${ }^{52}$ or a transaction is restructured to cut down on the continuity of operations, the rule is subject to manipulation. These uncertainties make it difficult to conclude a business transaction, because the parties cannot know what their subsequent costs will be. The likelihood of litigation is also increased, and with it the costs that the parties and the public pay to enforce the successorship rule. ${ }^{53}$

The successorship rule can impose direct costs on the union members, because the successorship rule may bind unions as well as employers. ${ }^{54}$ When the union has made a concession because the predecessor employer's business was failing, the successor employer may attempt to enforce the collective bargaining agreement against the union..$^{55}$ From the viewpoint of the predecessor employer this collective bargaining agreement becomes a premium contract from which he can profit if he can sell the business in such a way that the rule of contractual successorship will apply. The cost to the union's membership in this case is the difference between the contract wage rate and the higher wages that

49 See text and notes at notes 17-23 supra.

50 See note 20 supra.

51 See United Steelworkers of America v. Enterprise Wheel \& Car Corp., 363 U.S. 593 (1960); Torrington Co. v. Metal Prod. Workers Union, Local 1645, 362 F.2d 677 (2d Cir. 1966).

52 Cf. Retail Store Employees Union v. Lane's of Findlay, Inc., 260 F. Supp. 655 (1960).

53 See R. POSNER, Economic ANALYsis of LAW (to be published in 1973) (manuscript on file at The University of Chicago Law Review).

54 Cf. Bath Iron Works Corp. v. Bath Marine Draftsmen's Ass'n, 393 F.2d 407 (1968). In $B a t h$ the union argued that its contract was terminated by merger of the subsidiary corporation covered by the contract into the parent corporation. There was also another collective bargaining agreement in force between the union and the parent corporation. The Court held that arbitration was an appropriate means of determining which provisions of what contract should be enforced after the merger.

55 The Burns Court recognized that this was one possible application of the successorship rule working to the detriment of the union. NLRB v. William J. Burns Int'l Security Services, Inc., 40(r U.S. 272, 288 (1972). 
could be obtained from the more prosperous successor employer. The aggregate losses of unionized employees from this aspect of the successorship rule could, over the long run, offset gains in other successorship cases.

When the requirements of the successorship test are met and the contract is generally favorable to the union, the employer will bear the direct costs of the successorship obligation. As the Court recognized in Burns, a contract favorable to the union will reduce the price the predecessor employer can obtain when he sells the business, because it increases the buyer's cost of operating the business. ${ }^{56}$ However, the costs of successorship will encourage the successor employer to avoid hiring union members covered by the collective bargaining agreement in suffcient numbers to trigger successorship. Moreover, after Burns, the successor employer might also avoid the successorship rule by structuring the transaction to eliminate "privity" between himself and the predecessor employer. ${ }^{57}$ Only employers and not unions possess these opportunities to avoid the successorship obligation, making it possible for them to enforce collective bargaining agreements unfavorable to the union, while escaping contracts beneficial to the union. In sum, the successorship rule could prove more burdensome to unions than to employers.

Although it is impossible to know whether these costs of the successorship rule outweigh the supposed benefits, the successorship doctrine can also be criticized without resorting to a final weighing of costs and benefits. Virtually the same benefits can be obtained, at less cost, if the parties are left to negotiate for successorship clauses in collective bargaining agreements. ${ }^{58}$ Contractually provided successorship would suffer from fewer of the ambiguities and uncertainties connected with judicially imposed successorship, and thus involve fewer administrative

56 Id. at 287-88.

57 For example, an auction purchaser of the physical assets of a business should not be required to assume any of the business's contractual obligations. But cf. Uniform Commercial Code $\$ \S 6-101$ to -06 . See also NLRB v. Wayne Convalescent Center, 465 F.2d 1039 (6th Gir. 1972).

58 In National Maritime Union v. Commerce Tankers Corp., 325 F. Supp. 360 (S.D.N.Y. 1971), rev'd on other grounds, 457 F.2d 1127 (2d Cir. 1972), the court enjoined the employer from selling one of his ships without obtaining an agreement from the buyer to honor the collective bargaining agreement, as required by the successorship clause of the agreement. The court (Frankel, J.) concluded that the clause was not a violation of the antitrust laws or section $8(\mathrm{e})$ of the LMRA. In a later proceeding, however, the Board ruled that the clause violated the "hot cargo" provisions of section 8(e) of the LMRA. Commerce Tanker Corp., 196 N.L.R.B. No. 166, 80 L.R.R.M. 1198 (1972). However, the Board's ruling was confined to the specific context involving the purchase and sale of ships. 
costs..$^{59}$ Additionally, if the parties agreed upon a successorship clause, they would have the opportunity to apportion the direct costs of successorship between themselves, according to their own priorities and relative bargaining strengths. It would, of course, be difficult to enforce the successorship clause in all cases. For example, the business that is purchased might be integrated into a larger enterprise where another union already represents the employees and there is another collective bargaining agreement in force. ${ }^{60}$ These problems arise, however, whether successorship is controlled by judicially developed rules or by agreement between the parties. A final advantage to negotiated successorship is that it allows the parties to exercise their own judgment in accordance with the principle of freedom of contract in collective bargaining.

Failure to include a successorship clause in the collective bargaining agreement should be interpreted as an indication that the union would rather deal with the successorship issue when it arises, ${ }^{61}$ or that the union lacked the bargaining strength to obtain such a clause. It should not be necessary to rely on judicially imposed successorship in the absence of a successorship clause, because if the union is not strong enough to obtain a successorship clause, it is less likely to engage in a prolonged strike or other test of economic strength that could have adverse consequences for the public. ${ }^{62}$ Furthermore, it is questionable whether the successorship rule is, in fact, needed to protect the legitimate expectancies of the parties to the collective bargaining agreement. There is no indication the successorship situation is so unusual that the parties should not be expected to bargain over this subject as they would other matters affecting their rights under the contract. ${ }^{63}$ The rule, therefore,

59 The contract can be drafted to make it clear that the buyer-employer will be required to assume the collective bargaining agreement. Although there may be litigation over the proper interpretation of the successorship clause in cases where only part of the assets of the business are sold, there would be no need for the additional costs and delays of arbitration.

60 See McGuire v. Humble Oil \& Ref. Co., 355 F.2d 352 (2d Cir. 1966); cf. Bath Iron Works Corp. v. Bath Marine Draftsmen's Ass'n, 393 F.2d 407 (1968).

61 The union may even want a clause prohibiting assignment of the collective bargaining agreement, especially where a concession is granted to help a failing employer.

62 Moreover, application of the successorship rule where neither party is strong enough to obtain a successorship clause is exactly the kind of governmental interference with the substantive terms of the collective bargaining agreement which Congress sought to prohibit in section 8 (d). See note 39 supra.

63 In Wiley the union had bargained unsuccessfully for a successorship clause in the contract, although this bargaining had occurred in negotiations prior to those leading to the contract involved in the case, Inter-science Encyclopedia, 55 Lab. Arb. 210, 211 (1970) (Roberts, Arbitrator). The Supreme Court, however, was apparently unaware of this fact, 376 U.S. at 544. 
seems to provide a windfall for either the union or the employer depending on whether the contract rate of compensation is above or below the rate that could be obtained in a new round of bargaining. In the long run, stable bargaining relationships are created when the obligations of each party reflect their relative economic power, and not by judicially imposing obligations that have no relationship to the relative positions of the parties. It is doubtful, therefore, that the successorship rule can ever accomplish its aim of reducing the potential for industrial strife. For these reasons, contractually negotiated successorship appears to be in closer harmony with the goals of national labor relations policy.

\section{The Role of the Arbitrator in Successorship Cases}

The arbitrator plays a central but little noted role in enforcing the successorship rule. The duty to bypass the courts and submit disputes instead to an arbitrator can ordinarily be created only by contract. ${ }^{64}$ In Wiley, however, the successor employer had not consented to any arbitration provisions, but was nonetheless required to arbitrate. Although Wiley's conclusion that the "duty to arbitrate survives" the acquisi$\operatorname{tion}^{65}$ seems to be merely a convenient way of saying that, as a matter of law, the successor employer impliedly consented to be bound by the arbitration clause when he acquired the business, it also tends to obscure one of the fundamental differences between traditional labor arbitration and successorship arbitration. In the standard labor arbitration case, the authority of the arbitrator is prescribed by the scope of the arbitration clause. His duty is to interpret the provisions of the contract in accordance with the expressed intentions of the parties, in light of their bargaining history and the arbitrator's experience in the particular industry. ${ }^{68}$

In contrast, the successorship arbitrator must decide which provisions of the agreement will bind the nonconsenting party; he does not construe existing terms, but decides whether there are terms, and if so, what they are. ${ }^{.7}$ The successorship arbitrator's authority cannot, there-

64 United Steelworkers of America v. Enterprise Wheel \& Car Corp., 363 U.S. 593 (1960);

United Steelworkers of America v. Warrior \& Gulf Navigation Co., 363 U.S. 574 (1960).

65376 U.S. at $50-51$.

68 United Steelworkers of America v. Warrior \& Gulf Navigation Co., 363 U.S. 574 (1960).

67 There is some division of authority over whether the successorship arbitrator can enforce only part of the collective bargaining agreement against the successor employer. However, it is now generally accepted that the arbitrator may vary his award from the terms of the existing collective bargaining agreement, where he finds that it would be inequitable or impractical to order either party to comply fully with the existing contract. See United Steelworkers of America v. Reliance Universal, Inc., 335 F.2d 891 (3rd Gir. 1964); Goldberg, supra note 24, at 775-85. 
fore, be thought of as stemming from the arbitration clause, which the court finds has "survived." Rather, his authority is based on the court's power to delegate to an arbitrator the judicial power to determine the contractual duties of the parties. While a court itself perhaps has the power to fix obligations in this fashion, serious constitutional objections can be raised to the delegation of this authority to an arbitrator. Judicial reliance on the arbitrator to resolve successorship deprives the parties of their due process rights to a judicial resolution of their dispute.

Only rarely have the courts been required to define the due process right to obtain a judicial determination of one's legal obligations. In Boddie v. Connecticut, ${ }^{68}$ the Supreme Court held that a denial of due process resulted when the state charged fees that made divorce proceedings effectively unavailable to lower income applicants. The Court reasoned that where the state provided the only effective means for dissolving the marriage relationship, the state had the duty to provide the opportunity for access to the judicial system to all. Justice Harlan, writing for the majority, concluded that due process requires open access to the judicial system wherever the government has a monopoly over the only binding means of settling private disputes. ${ }^{69}$ Most due process requirements come into play only after one party has initially invoked the government's judicial power. At this point, the judicial system becomes the only effective means for resolving the conflict, and due process guarantees are necessary to protect both parties against an arbitrary or capricious exercise of that monopoly power. Among the due process guarantees are the right to notice and an opportunity to be heard, ${ }^{70}$ the right to a jury trial, ${ }^{71}$ the right to counsel, ${ }^{72}$ the right not to be arbitrarily denied an appeal, ${ }^{73}$ the right to subpoena witnesses, ${ }^{74}$ and other guarantees "fundamental" to a scheme of ordered liberty. ${ }^{75}$ Together, these rights define the character of the judicial process that the government must provide when its monopoly on coercive force is used to deprive anyone of life, liberty, or property.

Compulsory arbitration of successorship cases deprives the parties of important due process rights. Neither party can obtain a jury deter-

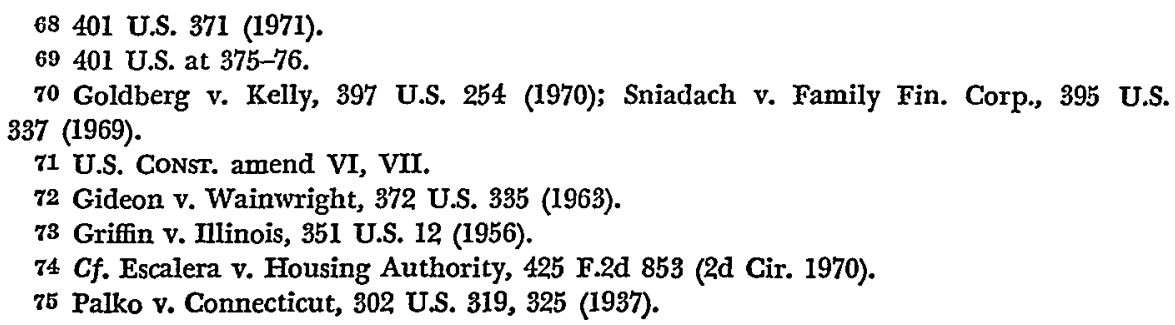


mination of issues of fact, because the arbitrator becomes the trier of fact. They lose the right to subpoena witnesses and obtain testimony under penalty of perjury. ${ }^{76}$ The arbitrator may not have legal expertise, and he is not sworn to uphold the law, or required to decide cases in accordance with law.77 His decisions are not appealable, and there is only very limited review of an arbitration award prior to its enforcement by a court. ${ }^{78}$ All of these rights are important to the due process protection given litigants in judicial proceedings, but not in arbitration.

In spite of these deficiencies, however, a number of considerations have been suggested as justifying arbitration of successorship issues. ${ }^{79}$ First, the Board and the courts are to a considerable degree bound by precedent, and, therefore, unable to take into account ad hoc considerations that may be more likely to lead to a peaceful solution of the dispute. For example, it would be difficult for the courts to find a legal justification for enforcing only part of the collective bargaining agreement against the successor employer, whereas the arbitrator is prepared to deal with equities and render compromise awards in the interest of reducing industrial strife. The problem with these arguments is that they merely confirm the extent of the party's loss when his opportunity to litigate in court is removed. Arbitration is more flexible precisely because it does not provide the protection of a judicial proceeding.

In contrast, the ordinary arbitration proceeding does not deny the parties due process of law. The Supreme Court in Boddie v. Connect$i c u t^{80}$ recognized that the due process right to obtain a judicial resolution of one's disputes can be waived. This is also the implication of the first Supreme Court cases, the Steelworkers Trilogy, construing labor arbitration clauses. ${ }^{81}$ In United Steelworkers of America $v$. Warrior \& Gulf Navigation Co. ${ }^{82}$ the Court held that the parties could only be

70 The arbitrator does not have the court's contempt power to compel the appearance of witnesses. B. Meltzer, Labor LAW Gases, Materials and Problems 746 (1970).

77 It may even be the arbitrator's duty to ignore the law when it would require him to violate the terms of the contract. See Meltzer, Labor Arbitration and Overlapping and Conflicting Remedies for Employment Discrimination, 39 U. CHr. L. REv. 30, 33 (1971).

78 See cases cited note 51 supra.

79 Goldberg, supra note 24, at 781-83; Note, Contract Rights and the Successor Employer: The Impact of Burns Security, supra note 24, at 582-86; The Supreme Court, 1971 Term, 86 HARv. L. REv. 247, 256-57 (1972).

80401 U.S. 371, 378-79 (1971). See also D.H. Overmeyer Co. v. Frick, 405 U.S. 174 (1972). 81 The Steelworkers Trilogy consists of United Steelworkers of America v. Enterprise Wheel \& Car Corp., 363 U.S. 593 (1960); United Steelworkers of America v. Warrior \& Gulf Navigation Co., 363 U.S. 574 (1960); and United Steelworkers of America v. American Mfg. Co., 363 U.S. 564 (1960).

82363 U.S. 574 (1960). 
ordered to submit to arbitration those disputes that were covered by the arbitration clause of the collective bargaining agreement. The implicit holding of this case, and its two companion cases, is that there is an initial right to have disputes settled by judicial proceedings unless that right has been contracted away by agreeing to arbitrate.

In the successorship cases the parties are compelled to arbitrate on the theory that the arbitration clause "survives," binding the successor employer-an implied agreement to arbitrate arising from the circumstances of the successor's acquisition of the business. Since any agreement to arbitrate, express or implied, amounts to a waiver of the parties' due process rights obtainable in a judicial proceeding, such a waiver should be governed by the standards applicable to other waivers of constitutional rights. It is well established that the courts will not readily imply a waiver of a constitutional right. ${ }^{83}$ In $D$. $H$. Overmeyer Co., Inc. of Ohio v. Frick Co. ${ }^{84}$ the Court applied this settled principle to confession of judgment clauses, holding that a litigant could "voluntarily, intelligently and knowingly [waive] the rights it otherwise possessed,"85 to answer and defend in a judicial proceeding. In the successorship cases, there is no adequate waiver, no intentional relinquishment of a known constitutional right. ${ }^{86}$

The central difficulty with relying on the arbitrator to resolve successorship disputes is that the arbitrator is called on to perform a role that is normally the function of the courts. ${ }^{87}$ Even if it is assumed that a successor employer has impliedly consented to arbitration, successorship disputes over the parties' contract rights cannot be resolved by arbitration as it is ordinarily understood, because the dispute is not over how the contract should be interpreted, but involves the prior question of whether there is a contract between the parties. ${ }^{88}$ When

83 See Brookhart v. Janis, 384 U.S. I (1966); Ohio Bell Tel. Co. v. Public Utility Comm'n, 301 U.S. 292 (1937). In Brookhart the Court said: "There is a presumption against the waiver of constitutional rights, see, e.g., Glasser v. United States, 315 U.S. 60, 70-71; and for a waiver to be effective it must be clearly established that there was an intentional relinquishment or abandonment of a known right or privilege, Johnson v. Zerbst, 304 U.S. $458,464, " 384$ U.S. at 4.

84405 U.S. 174 (1972). See also Swarb v. Lennox, 405 U.S. 191 (1972).

85405 U.S. at 187.

86 See Fay v. Noia, 372 U.S. 391 (1963); Johnson v. Zerbst, 304 U.S. 458 (1938).

87 In his landmark article on the subject, Dean Shulman said: "A proper conception of the arbitrator's function is basic. He is not a public tribunal imposed upon the parties by superior authority which the parties are obliged to accept. He has no general charter to administer justice for a community which transcends the parties. He is rather a system of self-government created by and confined to the parties." Shulman, supra note 15, at 1016.

88 The scope of the arbitration clause is not broad enough to permit the arbitrator to impose contractual terms on the successor because it does not give him authority to write new terms for new parties. 
the arbitrator undertakes to resolve this question he is essentially acting as a special master for the court, and his activities should be governed by rules similar to those governing the use of masters in federal courts, ${ }^{89}$ including a recognition of the long-standing principle that reference of a case for a final decision on questions of both law and fact ordinarily requires the consent of the parties..$^{90}$ At a minimum, the courts should recognize that the arbitrator is exercising a judicial and not a contractual authority, and apply an expansive standard for reviewing the decisions of the successorship arbitrator..$^{91}$

\section{CONCLUSION}

Wiley's successorship rule is difficult to reconcile with the principle that collective bargaining agreements must be voluntarily negotiated contracts, reflecting the bargaining strengths of the parties to the agreement, if they are to provide a sound structure for governing labor management relations. This comment has suggested that it is possible to find a construction of the LMRA that subsumes both the successorship rule and the principle of freedom of contract in collective bargaining. It, however, appears doubtful that on balance the benefits derived from the successorship rule justify an exception to the principle of freedom of contract fundamental to the LMRA. Moreover, it is difficult to find an appropriate forum for enforcing the successorship rule, because arbitration of successorship disputes forces parties to forego important constitutional rights. Although the successorship obligation might be imposed directly by the courts, as a means of avoiding constitutional difficulties with successorship arbitration, it is argued that a return to negotiated successorship provisions in collective bargaining agreements is more desirable.

\section{Lock Holmes}

89 FED. R. Crv. P. 53; 28 U.S.C. $\$ \S 631$ et seq. specifies the conditions and procedures for referring cases to masters.

90 See Kimberly v. Arms, 129 U.S. 512 (1888); Comment, An Adjudicative Role for Federal Magistrates in Civil Cases, 40 U. CHr. L. Rev. 584 (1973); cf. La Buy v. Howes Leather Co., 352 U.S. 249 (1957).

o1 In United Steelworkers of America v. United States Gypsum Co., 339 F. Supp. 302 (N.D. Ala. 1972) the court undertook a detailed review of a successorship arbitration award, vacating several provisions of the award. The case suggests that a different standard for reviewing successorship arbitration awards is developing. 